\title{
Determination of the swim bladder parasite Anguillicola crassus (Nematoda, Dracunculoidea) in the European Eel, Anguilla anguilla (Linnaeus, 1758) from the locality Çamalti Tuzla of Izmir Bay, Eastern Aegean Sea
}

\author{
Şule Gürkan ${ }^{1, a}$, Burcu Taylan ${ }^{1, b, *}$, Ertan Taşkavak ${ }^{1, c}$ \\ ${ }^{I}$ Department of Hydrobiology, Faculty of Fisheries, Ege University, 35100 Bornova, İzmir, Turkey
}

*Corresponding author

A R T I C L E I N F O A B S T R A C T

Research Article

Received : 23/09/2021

Accepted : 09/11/2021

We, here, aimed to determine the presence of Anguillicola crassus, a swim bladder parasite, in 89 (male: 45, female: 44) dead European eel specimens obtained seasonally between 2020-2021 from a regional fisherman, who has fished with fyke net in the locality Tuzla of Izmir Bay, Eastern Aegean Sea. Out of 21 male European eels caught in winter, only one specimen (TL: $48.5 \mathrm{~cm}$ and TW: $247.12 \mathrm{~g}$ ) had 23 swim bladder parasites (adult nematodes: 15, larvae: 8) and similarly, only one parasite was found in one specimen (TL: $37.5 \mathrm{~cm}$ and TW: $88.47 \mathrm{~g}$ ) of 8 eels caught in spring. No parasite was found in the female eels. At the examinations, it was determined that all adult Anguillicola crassus specimens were females and the minimum-maximum and average length values in adult and larval parasites were, respectively, $1.5-2.5 \mathrm{~cm}(1.99 \pm 0.31)$ and $0.7-1.3 \mathrm{~cm}$ $(1.025 \pm 2.40)$. Consequently, the species $A$. crassus, a swim bladder parasite, was found in

Keywords: European eels from the locality Çamalti Tuzla in two seasons (winter and spring) and this parasitic nematode were only in male eels. This study is a first and remarkable one having evidential value, which shows the presence of the species A. crassus among the eel population in the locality Çamalti Anguillicola crassus Swim bladder parasite Nematoda Anguilla anguilla Aegean Sea Tuzla of Izmir Bay. Besides, it is a population that should be monitored due to the status of Anguilla anguilla on the IUCN red list.

\section{Introduction}

With a wide range around the world, Anguilla anguilla (Linnaeus, 1758), also known as the European eel (Fam: Anguillidae) is a demersal and catadromic species that distributes from the Atlantic coasts of Scandinavia and Morocco to the Baltic, Black Sea and Mediterranean (Freyhof and Kottelat, 2008). In Turkey, it is known to be found in the rivers and streams opening to Aegean Sea, the Sea of Marmara, Black Sea and Mediterranean (Rad et al., 2013; Kanjuh et al., 2018). The European eels are evaluated as "CR" (critically endangered) category in the Red List given by IUCN, since their populations have decreased since the 1970s due to many reasons such as being an economic species, fishting pressure and habitat loss (Pike and Clock, 2020). As a result of the decrease in natural populations, European eel farming, which is mainly associated with recirculation systems, has come into prominence and while eel farming is highly developed mainly in France, Portugal, Spain and the United Kingdom, approximately 50 percent of total European eel production of over 10500 tones is provided from the Netherlands (FAO, 2009).

The genus Anguillacola containing parasitic nematodes has five species described in Anguilla anguilla. These are; Anguillicola crassus, Anguilla australis, Anguilla diffenbachii, Anguillicola novaezelandiae, Anguillicola papernai (Rolbiecki and Rokicki, 2005). Of these five species, A. crassus was first described among the European eels in Belgium (De Charleroy, 1986). Koie (1988) and Innal et al. (2018) reported that this parasitic species was accidentally transmitted to the European continent with the eels, A. japonicus, brought from Asia in the 1980s. Moreover, Han et al. (2008) also stated that A. crassus may cause population losses of the European eels due to its high pathogenicity.

Although the European eels are fundamentally piscivorous, they are also infected with A. crassus while 
feeding on intermediate hosts such as benthic crustaceans and copepods or on paratenic (transport) hosts such as amphibians, mollusks and insect larvae, which play an important role in the nematode's life cycle (Yalçın Özdilek and Solak, 2007). However, these parasites develop on the eel's swim bladder wall as the infected third-stage fish larvae pass into the fourth stage. By sucking the blood of their host, adult parasites live in the lumen of the swim bladder (De Charleroy et al., 1990; Moravec and Konecny, 1994; Sze'kely, 1994; Moravec, 1996; Moravec and Škoríková, 1998).

While investigations on $A$. crassus, a swim bladder parasite of $A$. anguilla, had started 30 years ago (Taraschewski et al., 1987; De Charleroy et al., 1990; Thomas and Ollevier, 1992; Rolbiecki and Rokicki, 2005; Gargouri et al., 2006; Knopf, 2006; Ashworth et al., 2009; Heitlinger et al., 2009; Weclawski et al., 2013), it is seen that the studies carried out in our country began in mid2000s and were scarce in number (Genç et al., 2005; Genç et al., 2008; Innal et al., 2018).

Population losses due to pathogenic reasons among European eels, extremely important for world and national fisheries, are very important for these fishes that are listed as critically endangered in the IUCN list. Therefore, the finding presented here for Izmir Bay, Eastern Aegean Sea is the first study for the prevalence of A.crassus, a parasitic species specific to the European eel population.

\section{Materials and Method}

We had met up with A.crassus, a swim bladder parasite, in two specimens of the 89 dead European eels, which were obtained seasonally between 2020-2021 from a local fisherman who has fished with fyke net in the locality Çamalti Tuzla of Izmir Bay (Figure 1, 2). The total length (TL, cm) and weight (TW, g) measurements of the fish specimens brought to the laboratory were measured with a ruler ( $1 \mathrm{~mm}$ scale) and a digital balance (a precision of 0.1 $\mathrm{g})$, respectively, and then their sex determinations were made by dissection.

The parasitic nematode worms on the swim bladder of the dissected fish specimens were collected with a finetipped forceps. In order to identify the parasite, determined as $A$. crassus, we used the descriptions given by Moravec and Taraschewski (1988) and Moravec (1994). Then, total lengths (TL, cm) of parasitic nematodes A. crassus with fusiform body, whose sexes were determined according to De Charleroy et al. (1990), were measured (Figure 3).

The prevalence percentage values $(\operatorname{Pr} \%)$ or incidence rate of the parasite samples found on the host and the intensity values (Int), which give the number of individuals belonging to the parasite species on a single host, were determined according to Bush et al. (1997).

\section{Results}

In this project, a total of $89(\delta: 45$, ○: 44) Anguilla anguilla specimens (36 in winter, 15 spring, 9 autumn and 29 summer) from the locality Tuzla of Izmir Bay were examined seasonally. Among the specimens, the two male European eels obtained in the seasons of winter and spring were infested with $A$. crassus, however, no parasite was found in female specimens. The length and weight values of two fish infected with $A$. crassus species were $48.5,37.5$ $\mathrm{cm}$ and $247.12,88.47 \mathrm{~g}$, respectively.

During the dissection, a total of 24 A. crassus specimens, of which 16 adult females (min-max: 1.5-2.5, $1.95 \pm 0.35 \mathrm{~cm}$ ) and 8 at larval stage (min-max: 0.7-1.3; $1.025 \pm 2.40 \mathrm{~cm}$ ) were determined (Figure 4). It has been seen that the nematode specimens densely located in the swimbladder region have gray-black color and fusiform body type.

While 15 adults and 8 larvae of the parasitic nematode were encountered in winter, 1 adult parasite in spring. The intensity range values of $A$. crassus among infected eels were calculated as 1-14, with an average of 7.5. While the prevalence $(\%)$ results of the parasites were $2.78 \%$ in the spring season, it was $6.67 \%$ in the winter season.

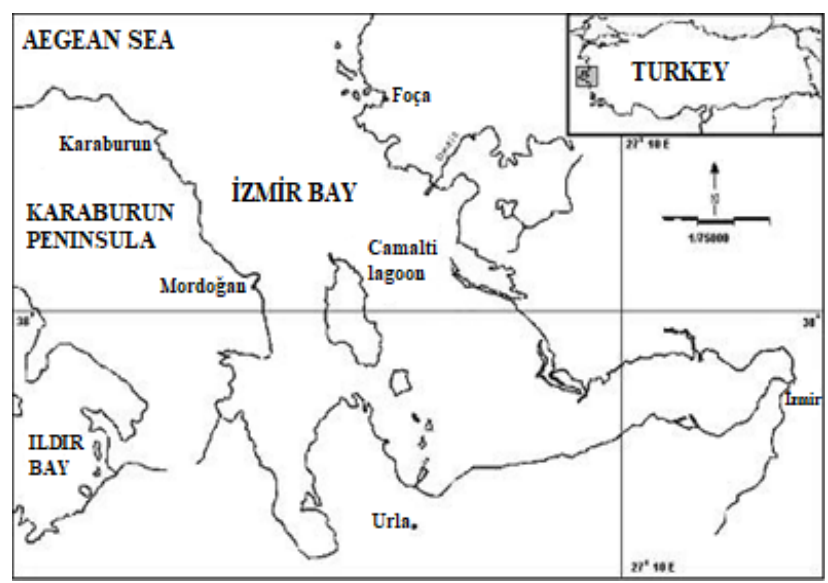

Figure 1. The locality Çamalti Tuzla of Izmir Bay where European eel specimens were caught

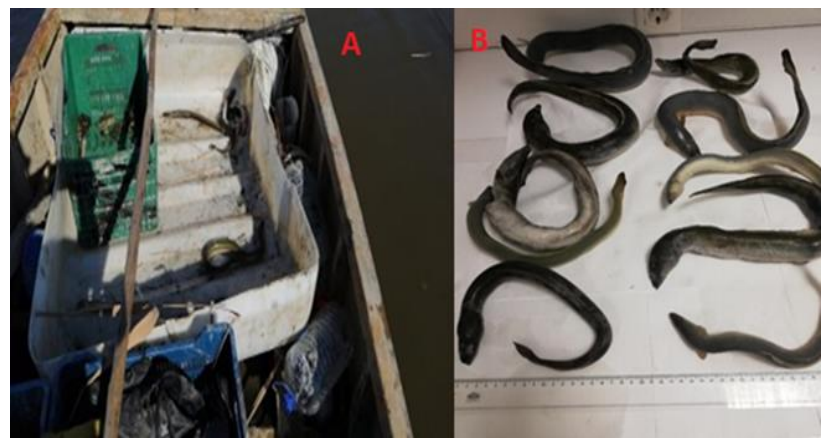

Figure 2. The European eel (Anguilla anguilla) specimens, caught in the locality Tuzla of İzmir Bay.

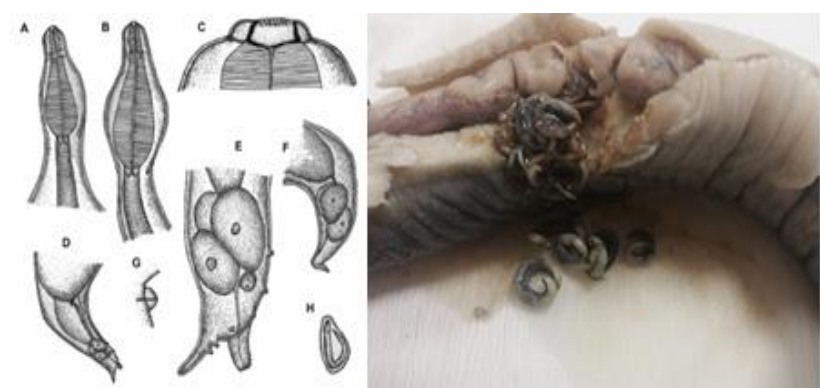

Figure 3. Anguillicola crassus (Moravec and

Taraschewski, 1988; Moravec, 1994) A, B - head end of male and female, $\mathrm{C}$ - buccal capsule of female, D posterior end of male, $\mathrm{E}$ - tail of male, $\mathrm{F}$ - caudal end of female, $\mathrm{G}$ - vulva, $\mathrm{H}$ - larva from uterus. 


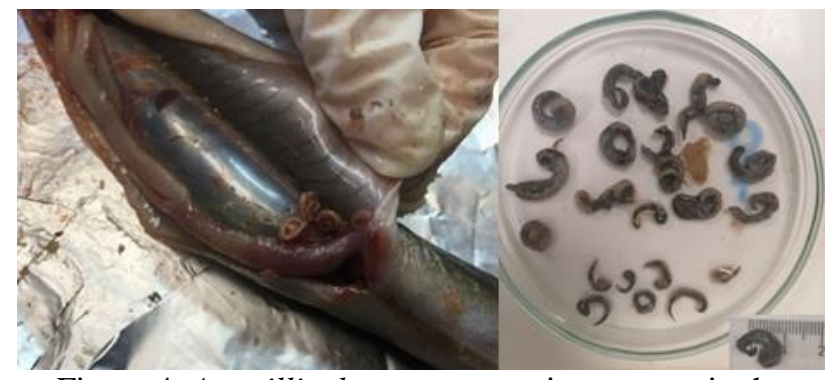

Figure 4. Anguillicola crassus specimens seen in the swimbladder region of Anguilla anguilla.

Table 1. First published records of the presence of Anguillicola crassus in various European countries (Rolbiecki and Rokicki, 2005).

\begin{tabular}{l|c}
\hline \multicolumn{1}{c|}{ Country } & First published report \\
\hline Austria & Konecny and Wais (1993) \\
Belgium & Balpaire et al. (1989) \\
Belarus & Bauer (1998) \\
Czech Republic & Moravec (1992) \\
Denmark & Koie (1988) \\
Estonia & Kangur (1994) \\
France & Dupont and Petter (1988) \\
Germany & Neumann (1985) \\
Greece & Balpaire et al. (1989) \\
Hungary & Szekely et al. (1991) \\
Ireland & Evans and Matthews (1999) \\
Latvia & Vismanis et al. (1999) \\
Italy & Canesti-Trotti (1987) \\
Macedonia & Cakic et al. (2002) \\
Netherlands & Van Banning et al. (1985) \\
Norway & Mo and Stein (1994) \\
Poland & Własow et al. (1991) \\
Portugal & Cruz et al. (1992) \\
Russia & Zaostrovceva (1993) \\
Spain & Balpaire et al. (1989) \\
Sweden & Hellström et al. (1988) \\
United Kingdom & Kennedy and Fitch (1990) \\
Yugoslavia & after Höglung and Thomas (1992) \\
Turkey & Genç et. al. (2005) \\
\hline
\end{tabular}

\section{Discussion}

It is well known fact that the stocks of European eels, which are exposed to common diseases caused by fungi, bacteria and viruses, have been decreasing (FAO, 2009). A. crassus, a parasitic nematode species, is the most common pathogen in European eels (Popielarczyk et al., 2012). Terech-Majewska et al. (2015) stated that this parasite occasionally had caused serious losses in European eel populations.

In Turkey, the parasitic nematode A. crassus, the swim bladder parasite of $A$. anguilla, was determined for the first time by Genç et al. (2005) and they found A. crassus specimens in 50 of 64 eels from Ceyhan River. In that study, the researchers had confirmed a total of 93 parasites in $A$. anguilla specimens belonging to July and November, and the determined prevalence values for these months were $82.86 \%$ and $72.41 \%$, respectively. As can be seen, the prevalence values given by tem are much larger than the values computed in our study. Pilcher and Moore (1993), who had investigated the presence of parasitic A. crassus in European eels from the Thames basin, calculated the prevalence range as $12-32 \%$. Since the sampling basin is in the tidal zone, they stated that the infection levels may be different due to the salinity differences between the sampling stations and the tolerance limits of the parasite's developmental stages to salt water. In their study that they had given the first record of $A$. crassus in eels from Ireland, Evans and Matthewss (1999) found the prevalence range of $2-14 \%$ in six lakes they had chosen from the Erne basin. Then, Evans et al. (2002), once again, stated the prevalence value as $9.9 \%$ in their study from the Erne basin. In our study, the computed prevalence values in winter and spring are $2.78 \%$ and $6.67 \%$, respectively, and when compared, they seem to be similar with the prevalence values given by Evans and Matthewss (1999) for the Erne basin. The reasons for the differences between studies in the prevalence values of this parasitic nematode are as follows; biotic and abiotic factors in the sampling area, the structure of the eel population having parasitic nematodes, the age of the fish (Innal et al., 2018), and the consumption of infected food groups (Polzer and Taraschewski, 1993). Findings in our study may suggest that the sex of the host is also important, as only male eels have these parasites.

As a result, this is a first and remarkable study, which has evidential value, since it shows the presence of the species $A$. crassus among the eel population in the locality Tuzla of Izmir Bay, Eastern Aegean Sea and it is a population that should be monitored due to the status of Anguilla anguilla on the IUCN red list.

\section{References}

Ashworth ST, Kennedy CR, Blanc G. 2009. Density-dependent effects of Anguillicola crassus (Nematoda) within and on its copepod intermediate hosts, CambridgeCore.

Bush AO, Lafferty KD, Lotz JM, Shostak AW. 1997. Parasitology meets ecology on its own terms: Margolis et al. revisited. J Parasitol, 83(4): 575-583. PMid:9267395. https://doi.org/10.2307/3284227

De Charleroy D, Grisez L, Thomas K, Belpaire C, Ollevier F. 1990. The life cycle of Anguillicola crassus. Dis. Aquat. Org., 8: 77-84.

De Charleroy D. 1986. Parasitologisch onderzoek van de Europese paling Anguilla Anguilla L. M. Sc. dissertation. Catholic University of Leuven, Belgium.

Evans DW, Matthews MA. 1999. Anguillicola carssus (Nematoda: Dracunculoidea): first documented record of this swimbladder parasite of eels in Ireland, J. Fish Biol., 55: 665-668.

Evans DW, Matthews MA, McClintock CA. 2002. The spread of the eel swimbladder nematode Anguillicola crassus through the Erne system, Ireland. J. Fish Biol., 59: 1416-1420.

FAO, 2009. Anguilla anguilla. In Cultured aquatic species fact sheets. Text by The Danish Aquaculture Development Group (DANAQ). Edited and compiled by Valerio Crespi and Michael New. CD-ROM (multilingual).

Kottelat M, Freyhof J. 2008. Handbook of European Freshwater Fishes. Switzerland/J. Freyhof, Berlin, 2007, 646 pp. ISBN: 9782839902984.

Froese R. 2006. Cube law, condition factor and weight-length relationships: history, meta-analysis and recommendations. J Appl Ichthyol, 22(4): 241-253.

Gargouri L, Abdallah B, Maamouri F. 2006. Spatio-temporal dynamics of the nematode Anguillicola crassus in Northeast Tunisian lagoonsDynamique spatio-temporelle du nématode Anguillicola crassus des lagunes du Nord-Est de la Tunisie, Comptes Rendus Biologies, 329(10): 785-789. 
Genç E, Şahan A, Altun T, Cengizler İ, Nevşat E. 2005 Occurrence of the Swimbladder Parasite Anguillicola crassus (Nematoda, Dracunculoidea) in European Eels (Anguilla anguilla) in Ceyhan River, Turkey. Turk J Vet Anim Sci, 29:661-663.

Genç E, Sangun MK, Dural M, Can MF, Altunhan C. 2008. Element concentrations in the swimbladder parasite Anguillicola crassus (nematoda) and its host the European eel, Anguilla anguilla from Asi River (Hatay-Turkey). Environ Monit Assess, 141:59-65.

Han Qiuju, Lu Jun, Duan Jizhou, Su Dongmei, Hou Xiaozhe, Li Fen, Wang Xiuli, Huang Baiqu. 2008. Gen5- and Elp3induced histone $\mathrm{H} 3$ acetylation regulates hsp70 gene transcription in yeast. Biochem, 409(3): 779-788. doi: https://doi.org/10.1042/BJ20070578.

Heitlinger EG, Dominik RL, Weclawski U, Han Y, Taraschewski H. 2009. Massive encapsulation of larval Anguillicoloides crassus in the intestinal wall of Japanese eels, Parasites and Vectors, 2:48.

Innal I, Ozmen O, Genc E. 2018. Infection of European Eel, Anguilla anguilla with the Nematode Anguillicoloides crassus from Some Estuarine Systems in Turkey. Turk J Fish and Aquat Sci, 19(11): 899-905.

Kanjuh T, Mrdak D, Piria M, Tomljanovic T, Joksimovic A, Talevski T, Milosevic D. 2018. Relationships of otolith dimension with body length of European eel Anguilla Anguilla (Linnaeus, 1758) from Adriatic catchment of Montenegro. Acta Adriatica, 59(1): 91-96. doi: 10.32582/aa.59.1.74.

Knopf K. 2006. The swimbladder nematode Anguillicola crassus in the European eel Anguilla anguilla and the Japanes eel Anguilla japonica: differences in susceptibility and immunity between a recently colonized host and the original host. J Helminthol, 80(2):129-36.

Køie M. 1988. Parasites in European eel Anguilla Anguilla (L.) from Danish freshwater, brackish and marine localities. Ophelia, 29: 301-310.

Kottelat M, Freyhof J. 2007. Handbook of European freshwater fishes. Publications Kottelat, Cornol and Freyhof, Berlin. 646 pp.

Mo TA, Steien SH. 1994. First observation of the eel swimbladder nematode Anguillicola crassus in Norway. Bull Eur Ass Fish Pathol, 14: 163.

Moravec F, Taraschewski H. 1988. Revision of the Genus Anguillicola-yamaguti, 1935 (Nematoda, Anguillicolidae) of the Swimbladder of eels, including descriptions of 2 new species, anguillicola-novaezelandiae sp-n and anguillicolapapernai sp-n. Folia Parasitologica. 35:125-46.

Moravec F. 1996. Aquatic invertebartes (snails) as new paratenic hosts of Anguillicola crassus (Nematoda: Dracunculoidea) and the role of paratenic hosts in the life cycle of this parasite. Dis. Aquat. Org., 27: 237-239

Moravec F, Škoriková B. 1998. Amphibians and larvae of aquatic insects as new paratenic hosts of Anguillicola crassus (Nematoda: Dracunculoidea), a swimbladder parasite of eels. Dis. Aquat. Org., 34: 217-222

Moravec F, Konecny R. 1994. Some new data on the intermediate and paratenic hosts of the nematode Anguillicola crassus Kuwahara, Niimi et Itagaki, 1974 (Dracunculoidea) a swimbladder parasite of eels. Folia Parasitol, 41: 65-70.
Pike C, Crook V, Gollock M. 2020. Anguilla anguilla. The IUCN Red List of Threatened Species 2020: e.T60344A152845178. https://dx.doi.org/10.2305/IUCN.UK.2020-2.rlts.t60344a15 2845178.en. Downloaded on 14 February 2021.

Pilcher MW, Moore JF. 1993. Distribution and prevalence of Anguillicola crassus in eels from tidal Thames's catchment. J Fish Biol., 43: 339-344.

Polzer M, Tarashewski H. 1993. Identification and chairacterization of the proteolytic enzymes in the developmental stages of the eel-pathogenic nematode Anguillicola crassus. Parasitol. Res. 79:24-27.

Popielarczyk R, Robak S, Siwicki KA. 2012. Infection of European eel, Anguilla anguilla (L.), with the nematode Anguillicoloides crassus (Kuwahara, Niimi et Itagaki, 1974) in Polish waters. Pol J Vet Sci, 15(2): 253-257. https://doi.org/10.2478/v10181-011-0142-4.

Rad F, Baris M, Bozaoglu SA, Temel GO, Üstündag M. 2013. Preliminary investigation on morphometric and biometric characteristics of female silver and yellow, Anguilla anguilla, from eastern Mediterranean (Goksu Delta/Turkey). Journal of FisheriesSciences.com, 7(3): 253.

Rolbiecki L. 2002. On the paratenic hosts in the life cycle of the nematode Anguillicola crassus in the Vistula Lagoon, Poland. Acta Ichtyol Piscat, 32(2): 109-116.

Rolbiecki L, Rokicki J. 2005. Anguillicola crassus - An alien nematode species from the swim bladders of eel (Anguilla anguilla) in the polish zone of the southern baltic and in the waters of northern Poland. Oceanol Hydrobiol St, Vol. XXXV, 1: 121-136.

Székely CS. 1994. Paratenic hosts for the parasitic nematode Anguillicola crassus in Lake Balaton, Hungary. Dis Aquat Org, 18: 11-20

Taraschewski H, Moravec F, Lamah T, Anders K. 1987. Distribution and morphology of two helminths recently introduced into European eel populations: Anguillicola crassus (Nematoda, Dracunculoidea) and Paraten uisentis ambiguus (Acanthocephala, Tenuisentidae). Dis Aquat Org, Vol. 3: 167-176.

Terech-Majewska E, Schulz P, Siwicki AK. 2015. Influence of nematode Anguillicoloides crassus infestation on the cellular and humoral innate immunity in European eel (Anguilla anguilla L.). Experimental immunology, 40(2):127-131.

Thomas K, Ollevier F. 1992. Population biology of Anguillicola crassus in the final host Anguilla Anguilla. Dis Aquat Org, 14: 163-170.

Weclawski U, Heitlinger EG, Baust T, Klar B, Petney T, San Han Y, Taraschewski H. 2013. Evolutionary divergence of the swim bladder nematode Anguillicola crassus after colonization of a novel host, Anguilla anguilla, Weclawski et al. BMC Evolutionary Biology, 13:78.

Yalçın Özdilek Ş, Solak K. 2007. The Feeding of European eel, Anguilla anguilla L. in the River Asi, Turkey. Electronic Journal of Ichthyology, 1: 26-34. 